\title{
Characteristics of Diffusion Tensor Imaging and Language Dysfunction Based on Nerve Fiber Injury in Patients with Acute Hemorrhagic Stroke
}

\author{
Hye Young Kim¹, Yeon Koo Kang ${ }^{2}$, Chul-Hee Choi ${ }^{1}$, Seong Hee Choi \\ 'Department of Audiology \& Speech-Language Pathology, The Graduate School of Health and Medical Science, Daegu Catholic University, \\ Gyeongsan, Korea \\ ${ }^{2}$ Pohang Stroke \& Spine Hospital, Pohang, Korea
}

\author{
신경섬유 손상에 따른 급성기 뇌출혈 환자의 확산 텐서 이미지와 언어장애 특성 \\ 김혜영 ${ }^{*}$ 강연구 ${ }^{2}$ 최철희 ${ }^{1} \cdot$ 최성희 ${ }^{1}$ \\ 대구가톨릭대학교 의료과학대학 언어청각치료학과 ${ }^{1}$, 에스포항병원 신경외과 ${ }^{2}$
}

\begin{abstract}
Purpose: Diffusion tensor imaging (DTI) technique visualizes to localize and grade nerve injury in brain. Since aphasia is serious common problems in patients with stroke, the present study aimed to explore the features of language dysfunction across the various aphasia types based on nerve fiber injury using a novel DTI in patients with acute hemorrhagic stroke. Methods: One normal adult male and five adults with acute hemorrhagic stroke (patient group) within 30 days from symptom onset participated in this study. Brain CT, MRI, DTI images and Paradise Korean-Western Aphasia Battery-Revised (PK-WAB-R) were tested within 1 month after brain damage. Two dorsal nerve fibers [superior longitudinal fasciculus (SLF), arcuate fasciculus (AF)] and two ventral nerve fibers [inferior longitudinal fasciculus (ILF), uncinate fasciculus (UF)] were investigated using DTI analysis. Results: Hematoma volumes were relatively larger and Aphasia Quotient scores were lower in P1, P3, and P5. Location of lesion on CT and MRI was same with P1, P5, but the aphasia type by PK-WAB-R was different from each other. This finding showed that there was no absolute relationship between the lesion site and aphasia type but the relationship between the nerve fiber injury site on DTI and aphasia type. Non-fluent patients (P1, P3, P5) showed SLF, AF damage whereas relatively good comprehensive patients (P2, P4, P5) showed relative preservation of ventral nerve tract except in P5 who showed UF damage. Conclusion: DTI provided the sensitive detection of nerve fiber damage in patients with cerebral hemorrhage and useful tool in predicting aphasia type and language dysfunction.
\end{abstract}

Key Words: Aphasia, Paradise Korean-Western Aphasia Battery-Revised, Diffusion tensor imaging, Hemorrhagic stroke, White matter nerve tract.

Received: September 22, 2018 / Revised: October 16, 2018 / Accepted: October 19, 2018

Correspondence: Seong Hee Choi, Department of Audiology \& Speech-Language Pathology, Research Institute of Biomimetic Sensory Control, and Catholic Hearing Voice Speech Center, Daegu Catholic University, 13-13 Hayang-ro, Hayang-eup, Gyeongsan 38430, Korea

Tel: +82-53-850-2542 / Fax: +82-53-359-0780 / E-mail: shgrace@cu.ac.kr

\section{INTRODUCTION}

실어증이란 언어 습득 시기가 지난 후에 뇌 손상으로 인하여 후천적으로 생기는 언어장애로, 주로 뇌졸중에 의해 대뇌의 우 성 반구의 언어중추가 손상되어 발생한다. 일반적으로 실어증은

(cc) This is an Open Access article distributed under the terms of the Creative Commons Attribution Non-Commercial License (https://creativecommons.org/licenses/by-nc/4.0) which permits unrestricted non-commercial use, distribution, and reproduction in any medium, provided the original work is properly cited.
언어 기능에 관여하는 실비우스열 주변부(perisylvian area)의 영역 즉, 전두엽의 브로카 영역(Brocás area), 측두엽의 베르니케 영역(Wernicke's area)과 그 외 시상(thalamus), 미상핵(caudate nucleus) 및 일부 선조(striatum) 등의 피질하 구조물의 손상에 의해 발생하고, 손상받는 범위에 따라 다양한 종류의 임상 양 상을 나타낸다(Jeong et al., 2009; Kim, 2012). Kim(2012)에 의하면, 각 유형의 실어증 환자들이 실어증 유형별 특색들을 모두 나타내지는 않는다. 실어증은 역동적이고 변화하는 증세 
이며, 뇌 손상 직후 초기 몇 달간에는 특히 변화가 많다. 또한 특 정 유형으로 분류된 환자의 언어 특색이 발병 후 언어 평가 시점 에 따라 다를 수도 있으며, 실어증 유형과 병소가 서로 일치하지 않는 경우도 많다. 특히 베르니케실어증이나 브로카실어증이 뇌 병소의 위치를 반영하는 유형의 경우에 반드시 그 병소로 인하 여 그 실어증이 나타난 것은 아닐 수도 있다. 실어증은 주로 피질 손상에 기인하지만, 기저핵이나 시상 등의 피질하 회백질이나 백 질 연결로(white matter pathways)의 손상에 의해서도 나타나는 데, 이는 $\mathrm{CT}$ (전산화 단층촬영검사), $\mathrm{MRI}$ (자기공명영상) 등을 포 함한 뇌영상술의 발전으로 인하여 순수한 피질하 뇌 손상 환자 들을 관찰할 수 있게 되었기 때문이다.

$\operatorname{Park}(2003)$ 은 26명의 실어증이 있는 급성기 뇌경색 환자를 대상으로, MRI 및 CT를 이용하여 병소의 위치에 따라 피질성 실어증, 피질하성 실어증으로 구분하였다. 또한, 한국판 웨스턴 실어증 검사(Korean-Western Aphasia Battery, 이하 K-WAB) 를 통해 실어증을 8 개의 유형으로 나누어 언어 유형의 변화와 예후에 대해 살펴본 결과, 실어증 증후군과 병소 부위와는 임상 해부학적 관계가 있음을 보고하였다. 그러나 Bohra et al.(2015) 은 실어증을 가진 출혈성 및 허혈성 뇌졸중 환자 60 명의 임상 해부학적 연관관계에 대한 연구에서, Hindi version WAB 검 사 결과, $35 \%$ 만이 실어증 양상과 병소 부위가 연관성이 있었다 고 밝혀, 병소 부위와 실어증 양상과의 절대적인 상관관계는 없 음을 보고하였다.

언어 기능이 유연하게 일어나기 위해서는 뇌 영역들 사이의 통합이 요구된다. 한 선행연구(Rilling et al., 2008)에 따르면, 전 측과 후측 뇌 영역들을 연결하는 백질로(white-matter tracts)가 다른 영장류에서는 관찰되지 않는다고 보고하면서, 백질로가 인 간 뇌에서 언어 처리에 중요한 역할을 함을 밝힘으로써 언어장 애의 양상이 대뇌피질 병변뿐만 아니라 백질 경로에서의 연결 성에 따라서도 달라질 수 있음을 입증하였다.

최근 들어 영상의학 기술의 발달로 확산 텐서 이미지(diffusion tensor imaging, DTI)를 통한 뇌 영상의 구현이 가능해졌 다. 확산 텐서 이미지란 백질 경로의 구조적 정보를 제공하는 영상기법으로, Hosomi et al.(2009)에 따르면, DTI란 백질에서 물 분자가 자유롭게 확산되지 않고 축삭의 장축을 따라 확산 되려는 성질을 이용하여 생체 내에서 신경섬유를 재구성해낼 수 있는 MRI의 최신 영상기법이다. 이 새로운 영상기법을 이용 하여 백질 경로에 대한 시각적인 관찰이 가능해짐으로써, 언어 장애의 양상이 백질의 신경섬유 손상에 의해서도 달라질 수 있 고, 백질 경로에서의 연결성 또한 중요함이 증명되었다(Rilling et al., 2008). Hosomi et al.(2009)은 DTI를 이용하여 13명의 좌 측중대뇌동맥 뇌경색 환자에서 활모양섬유다발(arcuate fasciculus, $\mathrm{AF})$ 의 좌측편향 비대칭성 소실이 실어증의 나쁜 예후를
예측할 수 있는 중요한 요소임을 밝혔다.

Kim et al.(2011)은 뇌출혈 및 뇌경색 환자 5명에서 AF에 대 한 확산 텐서 추적도(diffusion tensor tractography, DTT)가 고 식적 MRI 영상에서 관찰할 수 없는 $\mathrm{AF}$ 손상의 유무 및 중증도 에 대한 유용한 정보를 제공하며, 또한 실어증 양상의 분류에도 도움이 될 것이라고 하였다. 그리고 뇌출혈 환자에서 병소의 크 기가 비슷함에도 어떤 환자에서는 $\mathrm{AF}$ 의 연결성이 유지되어 마 비말장애의 소견을 보인 반면, 다른 환자에서는 $\mathrm{AF}$ 의 심한 손 상으로 추적도가 그려지지 않았고 전반실어증의 소견을 보였 다. 이는 뇌출혈 환자에서 병소의 부위나 크기가 비슷하더라도 $\mathrm{AF}$ 의 손상 정도에 따라 다양한 실어증 양상을 보일 수 있음을 시사한다. 또한 Kim \& Jang(2013)은 후속연구에서 25명의 뇌 출혈 및 뇌경색 환자를 대상으로 $\mathrm{AF}$ 의 손상 정도에 따라 세 그 룹(type $\mathrm{A}, \mathrm{AF}$ 의 추적도가 그려지지 않는 환자군; type $\mathrm{B}, \mathrm{AF}$ 의 단절이 관찰되는 환자군; type $\mathrm{C}, \mathrm{AF}$ 의 연결성이 유지된 환 자군)으로 나누고, 발병 후 약 6개월 시점의 $\mathrm{K}-\mathrm{WAB}$ 검사를 실 시한 결과, type $\mathrm{A}$ 환자군의 실어증지수(Aphasia Quotient, $\mathrm{AQ}$ ) 가 type $\mathrm{B}$ 와 type $\mathrm{C}$ 환자군보다 유의하게 낮았고, type $\mathrm{B}$ 와 type $\mathrm{C}$ 간에는 통계적 유의성이 없었다고 보고하였다. 따라서 발병 초기에 $\mathrm{DTT}$ 로 $\mathrm{AF}$ 를 검사하는 것이 $\mathrm{AF}$ 의 단절 유무와 관 계없이 실어증의 예후를 예측하는 데 도움이 됨을 밝혔다.

앞에서 언급한 선행연구들은 주로 $\mathrm{AF}$ 에 한정된 연구인 반면, $\mathrm{AF}$ 이외에도 여러 백질 신경섬유들 즉, 상종단다발(superior longitudinal fasciculus, SLF), 하종단다발(inferior longitudinal fasciculus, ILF), 갈고리다발(구회속; uncinate fasciculus, $\mathrm{UF)} \mathrm{등이} \mathrm{언어와} \mathrm{관련되어} \mathrm{있음이} \mathrm{보고되었다.} \mathrm{Breier} \mathrm{et} \mathrm{al.}$ (2008)은 20명의 좌측반구 뇌졸중 환자에서 DTI를 이용하여 $\mathrm{SLF}$ 및 $\mathrm{AF}$ 의 손상이 따라말하기, 알아듣기 능력과 연관이 있 음을 밝혔다. 또 Galantucci et al.(2011)은 원발성 진행성 실어증 환자의 세 가지 하위 유형 연구에서 SLF, ILF 및 UF와 같은 언 어 기능에 관련된 신경섬유 손상을 연구하였는데, SLF를 기능 에 따라 전두-각회 상종단다발(frontoangular SLF), 전두-연상 회 상종단다발(frontosupramarginal SLF), 일반적으로 $\mathrm{AF}$ 로 알려진 전두-측두엽 상종단다발(frontotemporal SLF), 측두두정엽 상종단다발(temporoparietal SLF)의 하위 구성 요소로 구분하여 연구하였다(Figure 1). 이 연구에 의하면, 비유창형은 전두엽-두정엽, 전두엽-측두엽 부위 등쪽 경로(dorsal tract)의 손상을 보이고, 의미형에서는 양측 배쪽 경로(ventral tract) 및 좌측 측두엽-두정엽 부위 등쪽 경로의 손상을 보였으며, 특히 배쪽 경로의 손상이 다른 하위 유형에 비해 심했다. 발화부족형 에서는 좌측 측두엽-두정엽 부위 등쪽 경로의 손상을 보였다.

Lee et al.(2015)은 청각적 이해에 대한 백질 연구에서 음운 론적, 의미론적, 통사론적 측면을 고려하여 각 신경섬유 다발 

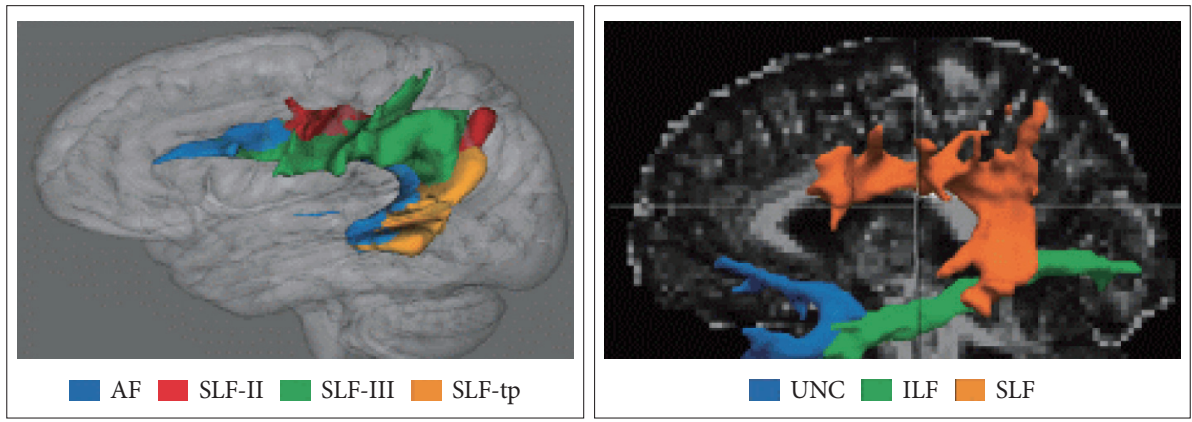

Figure 1. Language-related nerve fibers. AF: arcuate fasciculus, SLF: superior longitudinal fasciculus, SLF-II: frontoangular SLF, SLF-III: frontosupramarginal SLF, SLF-tp: temporoparietal SLF, UNC: uncinate fasciculus of craniocaudal, ILF: inferior longitudinal fasciculus.

의 신경생리학적 기능을 살펴보았다. 연구 결과에 따르면, 등쪽 경로인 SLF는 주로 음운론, 통사론적 이해에, 또 다른 등쪽 경 로인 $\mathrm{AF}$ 는 음운론, 의미론, 통사론적 언어 처리에 모두 관여하 는 것을 확인하였다. 아울러, 배쪽 경로인 ILF와 UF는 의미론, 통사론적 이해에 관여하며, $\mathrm{AF}$ 는 특히 '복잡한' 통사구조 처리 에 중요하고, UF는 '단순한' 통사구조 처리에 중요하다고 하였 다. 백질 경로들은 언어 중추에 해당하는 피질 영역들 사이를 서로 연결해주는 역할을 하는데, 언어 이해의 음운론, 의미론, 통사론적 처리 과정은 각각의 특성상 특정 경로를 경유하게 된 다. 음운 이해에는 AF가, 의미 이해에는 UF, ILF, 극포, 뇌궁, $\mathrm{AF}$ 등이, 통사 이해에는 $\mathrm{SLF}$ 및 $\mathrm{AF}$ 등이 주로 관여한다. 따라 서 청각적 이해의 중추에 해당하는 피질이 손상되지 않았다 하 더라도 피질 손상과 유사한 언어 이해 문제가 야기될 수 있다고 하였다(Figure 2).

따라서, 본 연구에서는 실어증을 가진 뇌졸중 환자 중 급성 기 뇌출혈 환자만을 대상으로 하여 언어적 양상을 살펴보고자 한다. 혈전으로 인해 뇌혈관이 막혀 뇌의 일부가 괴사함으로써 발생하는 뇌경색과는 달리, 뇌출혈은 뇌혈관의 약한 부분이 터 져서 생긴 출혈이 원인이 되어 발생한다. 본 연구의 대상을 특 별히 뇌출혈 환자로만 한정한 이유는 언어장애에서 병소 부위 자체뿐만 아니라 백질 연결성에 대한 손상 유무가 중요한 영향 을 미친다는 선행연구의 결과를 지지하기 위해서이다. 왜냐하 면 자발성 뇌출혈의 호발 부위는 기저핵, 시상, 뇌간 및 소뇌 등 과 같이 뇌의 심부에서 주로 발생하므로 백질 신경섬유 손상을 연구하기에 적합하리라 예측되기 때문이다. 먼저 CT와 MRI를 이용하여 뇌출혈 환자의 병소 부위와 크기를 확인한 후 그에 따 른 언어적 특성을 관찰하고, 선행연구에서 보고된 바와 같이 병 소 부위와 실어증 유형 간에 임상해부학적으로 일치되지 않는 경우에 대해 신경섬유의 손상 부위나 손상의 정도가 언어장애 의 양상에 어떠한 영향을 미치는지를 알아보고자 한다. 아울러, DTI를 이용하여 AF, SLF, ILF 및 UF 등의 신경섬유 다발을 통 합적으로 관찰하여 그 손상 부위와 손상의 정도를 비교분석함 으로써, 신경섬유 손상에 따른 뇌출혈 환자들의 언어적 양상이 실제로 어떻게 나타나는가를 살펴보고자 한다(Figure 3).

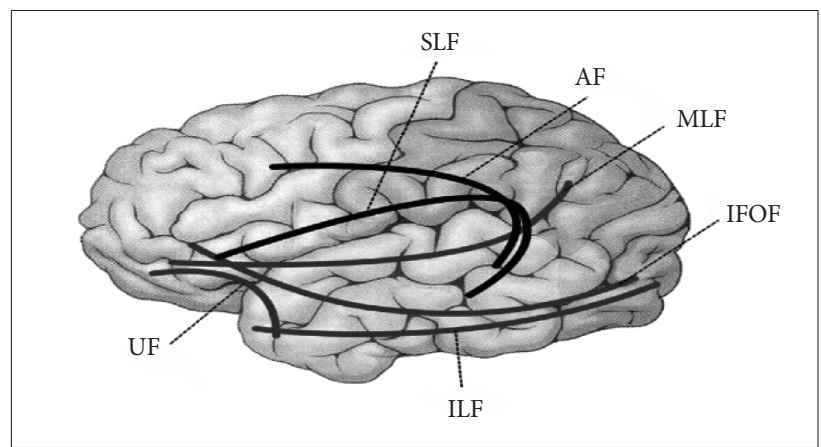

Figure 2. Association fibers of dorsal and ventral pathways. AF: arcuate fasciculus, IFOF: inferior fronto-occipital fasciculus, ILF: inferior longitudinal fasciculus, MILF: middle longitudinal fasciculus, SLF: superior longitudinal fasciculus, UF: uncinate fasciculus.

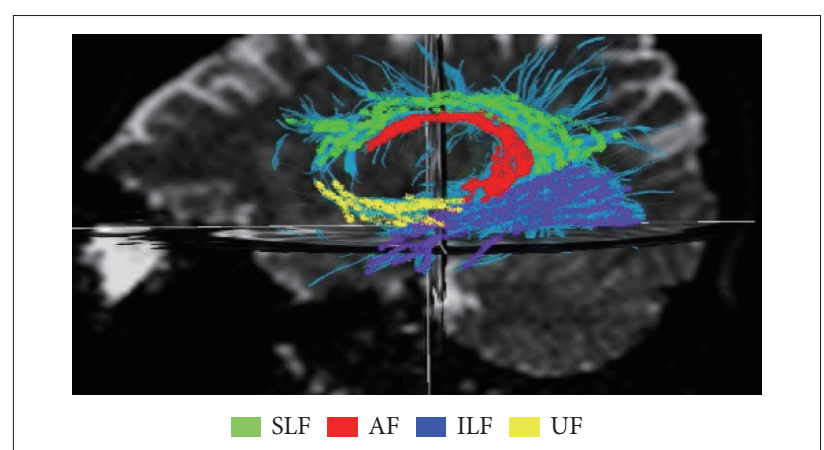

Figure 3. Nerve fibers using DTI in a normal male (dorsal tract: SLF, AF; ventral tract: ILF, UF). DTI: diffusion tensor imaging, SLF: superior longitudinal fasciculus, AF: arcuate fasciculus, ILF: inferior longitudinal fasciculus, UF: uncinate fasciculus.

\section{MATERIALS AND METHODS}

본 연구에서는 소수의 뇌출혈 환자(5명)와 정상인(1명)을 대 상으로 뇌 손상 부위에 대한 영상의 시각적 평가와 언어장애의 특성을 분석하고 그 내용을 기술하였다.

\section{연구 대상}

본 연구는 포항 지역에 위치하고 있는 뇌혈관전문병원인 S 병 원을 내원한 급성기 뇌출혈 환자 5 명과 정상대조군 47세 남성 1 명을 대상으로 하였다. 6 명 모두 오른손잡이이며, 환자군은 남 
Table 1. Demographic information of participants

\begin{tabular}{cccccc}
\hline Case & Sex & Age & Dominant hand & Time from onset (days) & Underline disease \\
\hline Normal & M & 47 & Rt. & - & - \\
Patient 1 & M & 52 & Rt. & 10 & High blood pressure \\
Patient 2 & F & 65 & Rt. & 3 & \\
Patient 3 & M & 53 & Rt. & 21 & High blood pressure, diabetes, hyperlipedemia \\
Patient 4 & M & 62 & Rt. & 21 & High blood pressure \\
Patient 5 & M & 43 & Rt. & 20 & \\
\hline
\end{tabular}

M: male, F: female, Rt.: right

성 4 명, 여성 1 명으로 평균 연령은 55 세이다. 연구 참여자의 인 구학적 및 임상적 정보는 Table 1과 같다. 환자의 선정 기준은, 뇌출혈 이외의 다른 원인에 따른 뇌 손상이 없으며, 청각 기능 에 이상이 없는 환자이다. 또한, 검사 방법을 이해하고 실시해 야 하므로, Paradise PK-WAB-Revised (PK-WAB-R) 기준으 로 $\mathrm{AQ}$ 가 2점 미만인 환자와 심한 말실행증 및 마비말장애를 동반한 환자는 제외하였다(Kim \& Na, 2012). 말실행증 및 마 비말장애를 동반한 환자를 제외한 이유는, 실어증 환자가 보이 는 음소착어 등의 문제를 초보 임상가가 말실행증이나 마비말 장애로 인한 말운동 오류와 구분하기 어렵기 때문이다.

\section{연구 절차}

\section{CT 및 MRI 촬영}

병소 부위와 병소 크기를 알아보기 위해 발병 1 개월 이내에 $\mathrm{CT}$ 와 MRI를 촬영하였다. CT 영상에서는 밀도가 높은 뼈와 같은 조직은 흰색으로 나오고, 밀도가 가장 낮은 뇌척수액 등 은 검게 나타난다. 오래전에 손상된 조직은 주변 조직보다 어둡 게 나오는데, 이는 이 조직이 밀도가 낮은 뇌척수액 같은 것으로 채워져 있기 때문이다. 반대로 최근에 출혈이 일어났던 자리는 더 밝은 색을 띠게 되는데 이는 두뇌 조직보다 더 밀도가 높기 때문이다. MRI는 양성자의 움직임을 왜곡시키기 위해 자기장을 사용하는 기법으로, CT에 비해 영상의 공간적 해상도가 횔씬 우수하다(Banich \& Compton, 2014).

본 연구에서는 64-row-multi-slice CT scanner (Brilliance 64 CT scanner; Philips Healthcare, Best, the Netherlands)로 CT 영상을 얻었고, 1.5T MR imaging (Achieva; Philips Healthcare) 장비로 MRI 영상을 얻었다. CT, MRI 영상은 수평면(axial plane)에서 얻었다.

병소 크기는 출혈량(volume of hematoma)을 기준으로 하였 는데, 병소 부위가 정형화된 구조가 아니므로 영상에서 병소 부위의 대략적인 가로, 세로, 높이를 구하여(가로 $\times$ 세로 $\times$ 높이 $\div 2$ 로 계산한 후 $\mathrm{cc}$ 로 나타내었다. 출혈량 $30 \mathrm{cc}$ 를 기준 으로 $30 \mathrm{cc}$ 이상이면 다량의 혈종(large volume of hematoma)
으로, $30 \mathrm{cc}$ 미만이면 소량의 혈종(small volume of hematoma) 으로 나타내었다.

\section{$\mathrm{PK}-\mathrm{WAB}-\mathrm{R}$ 실시}

발병 1개월 이내로 PK-WAB-R을 실시하였다. 본 연구에서 는 스스로 말하기, 알아듣기, 따라말하기, 이름대기, 낱말찾기 및 읽기, 쓰기 등 언어적 능력만을 평가하였다. 각 영역별로 총점 을 산정하며, 8 개 영역의 총점들을 합하여 실어증지수(AQ)와 언 어지수(Language Quotient, LQ)에 대한 점수를 산출하였다. $\mathrm{AQ}$ 는 언어장애의 심각도를 의미하는데, 스스로 말하기, 알아듣 기, 따라말하기, 이름대기 및 낱말찾기의 5 개 영역 점수를 계산 한다. $\mathrm{LQ}$ 는 $\mathrm{AQ}$ 에 읽기와 쓰기 점수를 더하여 산출한다. 검사 소요시간은 40 분 1 시간 30 분 정도였으며, 검사의 전 과정을 녹 음하는 동시에 수기로 기록하였다.

\section{DTI 영상 촬영}

본 연구에서는 1.5T MR imaging (Achieva) 장비로 MRI 영 상을 얻었고 $1.5 \times 1.5 \times 2 \mathrm{~mm}^{3}$ 크기의 체적소(isovoxel), $\mathrm{b}$ 값 1,000 으로 하여 15 방향으로 DTI 영상을 얻었다. 관상면(coronal plane)에서 다발성 관심 영역(region of interest, ROI) 기법 으로 $\mathrm{SLF}, \mathrm{AF}$ 의 후방부의 추적도를 그렸고, 시상면(sagittal plane)에서 단일 ROI 기법으로 $\mathrm{AF}, \mathrm{ILF}, \mathrm{UF}$ 의 추적도를 그렸 다. 또한, Galantucci et al.(2011)의 분류에 따라 등쪽 신경섬유 인 SLF 및 AF와 배쪽 신경섬유인 ILF 및 UF로 크게 구분하였 으며, 손상 부위는 $\mathrm{AF}, \mathrm{SLF}$ 의 전·중·후방 및 $\mathrm{ILF}$ 와 UF로 구 분하였다.

신경섬유는 손상 정도에 따라 조작적 정의를 내려 $0=$ 손상 없음, 1 = 좌측편향 비대칭성의 소실만 보인 경우(경도), 2 = 좌 측편향 비대칭성의 소실 및 단절을 보인 경우(중도), 3 = 심한 손상으로 추적도를 그릴 수 없는 경우(심도)로 나누어 기술하 였다. 신경섬유의 연결성 단절 여부는,+ -로 표시하였고 소실 정도를 기술하였다. 좌측편향 비대칭성의 소실 유무 또한,+로 표시하였다.

좌측편향 비대칭성이란 DTI를 이용한 좌우 뇌의 신경섬유 
추적도에서, 일반적으로 정상인의 경우 우측 뇌보다 좌측 뇌의 신경섬유가 상대적으로 더 많아 비대칭을 이루는 것을 말한다. Hosomi et al.(2009)에 따르면 이 좌측편향 비대칭성의 소실은 실어증의 나쁜 예후를 예측할 수 있는 중요한 요소로, 실어증 환자의 경우는 좌측 뇌 손상으로 인해 좌측 뇌의 신경섬유가 손상되므로 신경섬유의 좌측 편향성이 유지되지 않는다.

본 연구의 DTI 영상에서는 신경섬유의 손상 부위(nerve fiber injury)와 손상 정도(severity of injury), 단절(disconnection)의 여부 및 소실 정도, 좌측편향 비대칭성(asymmetry)의 소실을 기준으로 관찰하였다.

\section{증례 기록지 작성}

증례 기록지에는 성별, 나이, 손잡이, 교육 정도, 기저 질환, 발병 일수, 뇌출혈 발병 부위, 출혈량, $\mathrm{AQ}, \mathrm{LQ}$, 중증도, 실어증 유형, DTI 영상을 기록했다. 손잡이는 언어의 우성 반구를 알 기 위해 기록하였고, 기저질환은 뇌출혈에 영향을 미치는 질병 들, 특히 고혈압, 당뇨, 고지혈증, 심장병 등과 같이 뇌출혈 발병 의 원인 질환을 기록하였다. 개인정보 보호를 위해 환자의 신상 정보는 의무기록실을 통해 기호화(coding)하여 작성하였다.

\section{RESULTS}

\section{자료 분석}

\section{$\mathrm{CT}, \mathrm{MRI}$ 및 $\mathrm{DT} \mid$ 의 영상의학적 소견}

정상인과 환자의 CT와 MRI 수평면 소견은 Figure 4와 같다. 정상인의 경우, $\mathrm{CT}$ 영상은 첫 번째 그림에서 보듯이, 밀도가 높 은 뼈와 같은 조직은 흰색으로 나오고, 밀도가 가장 낮은 뇌척 수액 등은 검게 나타났다. CT와 MRI 영상 모두에서 피질 영역 의 손상이 없었고, 피질하 영역도 오래된 손상 조직으로 인한 어두운 색이나 최근의 출혈로 인한 밝은 부분 없이 깨끗하게 유 지되어 있다.

두 번째 영상은 52세의 브로카실어증 환자(P1)의 CT와 MRI 영상으로, 뇌출혈 발병 일수는 10 일이었다. 영상에서 확인된 병 소 부위는 피질 영역(cortical)의 전두엽(frontal lobe)과 피질하 영역(subcortical)인 좌측 피각부(left putamen)이고, 출혈량은 $36 \mathrm{cc}$ 로 관찰되었다.

세 번째 영상은 65세의 여성 명칭실어증 환자(P2)의 CT와 MRI 영상이다. 뇌출혈 발병 일수는 3 일이었다. 환자의 영상에서 확인된 병소 부위는 피질하 영역인 좌측 피각부(left putamen) 이고, 피질 영역의 손상은 없었다. 병소의 크기는 $4 \mathrm{cc}$ 로 관찰 되었다.

네 번째 영상은 53세의 남성 전반실어증 환자(P3)의 CT와
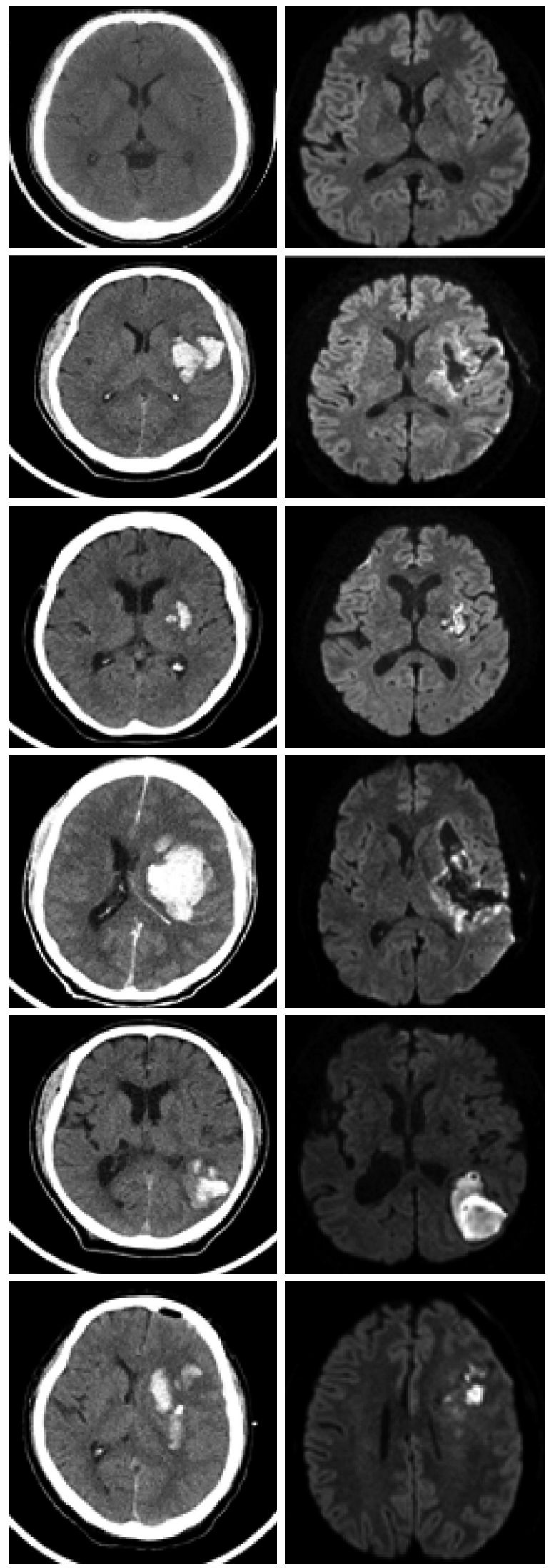

Figure 4. CT (left) and MRI (right) brain imaging in a normal male speaker and aphasia patients (P1, P2, P3, P4, P5) from top to buttom. 
Table 2. Lesions and volumes of hematoma based on aphasia type

\begin{tabular}{lllc}
\hline \multicolumn{1}{c}{ Case } & \multicolumn{1}{c}{ Lesion } & Cortical/subcortical & Volume of hematoma (cc) \\
\hline P1 (B) & Lt. putamen/frontal lobe & Both & 36 \\
P2 (A) & Lt. putamen & Subcortical & 4 \\
P3 (G) & Lt. putamen/temporal lobe & Both & 80 \\
P4 (TCS) & Post temporal lobe/parietal lobe & Cortical & 18 \\
P5 (W/TCS) & Lt. putamen/frontal lobe & Both & 75 \\
\hline
\end{tabular}

B: Broca, A: anomia, G: global, TCS: transcortical sensory, W: Wernicke, Lt.: left

MRI 영상이다. 뇌출혈 발병 일수는 21일이었다. 영상에서 확인 된 병소 부위는 피질 영역의 측두엽(temporal lobe)과 피질하 영 역의 좌측 피각부(left putamen)이고, 병소의 크기는 $80 \mathrm{cc}$ 로 관찰되었다.

다섯 번째 영상은 62세의 남성 연결피질감각실어증 환자(P4) 의 CT와 MRI 영상으로 뇌출혈 발병 일수는 1 일이었다. 영상에 서 확인된 병소 부위는 피질 영역의 후방 측두엽(post temporal lobe)과 두정엽(parietal lobe)이고, 피질하 영역의 손상은 없었다. 병소의 크기는 $18 \mathrm{cc}$ 로 관찰되었다.

여섯 번째 제일 마지막 영상은 43세의 남성 베르니케실어증 과 연결피질감각실어증으로 진단된 환자(P5)의 CT와 MRI 영상 으로, 뇌출혈 발병 일수는 20 일이었다. 병소 부위는 피질 영역의 전두엽(frontal lobe)과 피질하 영역의 좌측 피각부(left putamen) 이며, 병소의 크기는 $75 \mathrm{cc}$ 로 관찰되었다.

CT와 MRI 영상을 통해 확인한 각 환자별 병소 부위와 병소 크기는 Table 2와 같다. Table 2에서, 피질 영역과 피질하 영역 양쪽 모두 손상을 입은 P1, P3, P5의 경우 피질 영역 또는 피질 하 영역 한쪽만 손상을 입은 P2, P4에 비해 출혈량으로 나타난 병소의 크기가 각각 $36,80,75 \mathrm{cc}$ 로 큰 것이 관찰되었다.

한편, Figure 5는 정상인과 실어증 환자의 DTI 영상 소견이 다. Figure 5의 맨 위 첫 번째 영상은 본 연구에 참여한 오른손 잡이인 정상인의 우뇌, 좌뇌, 양측 뇌의 DTI 영상에 해당한다. 정상인의 경우 좌측과 우측을 비교해볼 때, 정상적인 좌측편향 비대칭성을 보이고 있으며, AF, SLF, ILF 및 UF의 단절이나 소 실 부분이 없는 것으로 관찰되었다. 환자군의 경우 좌측편향 비 대칭성에서 감소 경향을 띠는 데 반해, 정상대조는 좌측편향 비 대칭성에서 증가 경향이 관찰되는데 이는 교육과 학습에 따른 좌뇌의 상대적 발달이 원인인 것으로 추측된다.

두 번째 영상은 52세의 남성 브로카실어증 환자(P1)의 우뇌, 좌뇌, 양측 뇌의 DTI 영상을 나타낸 것이다. DTI를 통해 관찰 한 결과, $\mathrm{AF}$ 와 $\mathrm{SLF}$ 중간 부위의 단절을 보이며, SLF에 심한 좌측편향 비대칭성의 소실이 관찰된다. ILF와 UF는 비교적 잘 유지되었다. 본 연구에서의 nerve fiber injury의 조작적 정의에 따르면 등쪽 신경섬유의 중증도는 3 , 배쪽 신경섬유의 중증도 는 0 에 해당하였다.

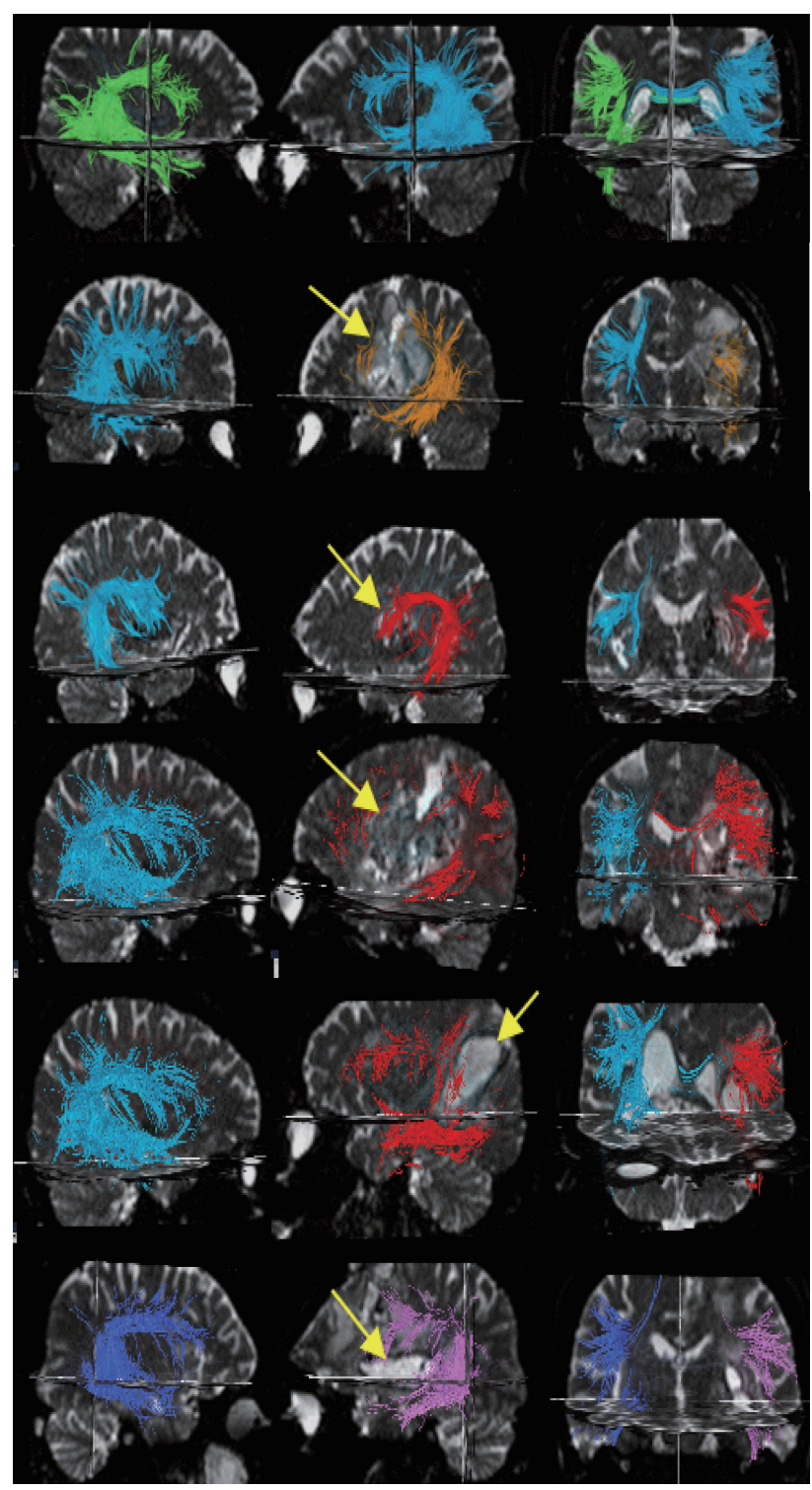

Figure 5. Nerve fibers in right, left, and both side of brain using diffusion tensor imaging in a normal male speaker and aphasia patients (P1, P2, P3, P4, P5) from top to buttom. Yellow arrows indicate each lesions.

세 번째 영상은 P2 환자의 우뇌, 좌뇌, 양측 뇌의 DTI 영상을 나타낸 것이다. DTI 영상을 통해 관찰한 결과, 신경섬유의 단절 이나 소실은 관찰되지 않았고, SLF에 약간의 좌측 편향 비대 
칭성의 소실만 관찰되었다. 본 연구에서의 nerve fiber injury의 조작적 정의에 따르면 등쪽 신경섬유의 중증도는 1 , 배쪽 신경 섬유의 중증도는 0 에 해당하였다.

네 번째 영상은 P3 환자의 우뇌, 좌뇌, 양측 뇌의 DTI 영상을 나타낸 것이다. DTI 영상을 통해 관찰한 결과, SLF 후방 부위 의 단절이 관찰되었고, SLF 전방 부위에 심한 좌측편향 비대칭 성의 소실을 보였다. AF 및 SLF의 중반부에서 추적도가 그려 지지 않았고, ILF 전방 부위 및 UF의 추적도도 그려지지 않았 다. 본 연구에서의 nerve fiber injury의 조작적 정의에 따르면 등쪽 신경섬유의 중증도는 3 , 배쪽 신경섬유의 중증도도 3에 해당하였다.

다섯 번째 영상은 P4 환자의 우뇌, 좌뇌, 양측 뇌의 DTI 영상 을 나타낸 것이다. DTI 영상을 통해 관찰한 결과, AF 및 SLF 후방 부위인 베르니케 부위에서 불완전한 단절을 보였고, SLF 전방 부위에 심한 좌측편향 비대칭성의 소실이 관찰되었다. ILF와 UF는 유지되었으며, 본 연구에서의 nerve fiber injury 의 조작적 정의에 따르면 등쪽 신경섬유의 중증도는 2 , 배쪽 신 경섬유의 중증도는 1 에 해당한다.

여섯 번째 제일 마지막 영상은 P5 환자의 우뇌, 좌뇌, 양측 뇌 의 DTI 영상을 나타낸 것이다. DTI 영상을 통해 관찰한 결과, $\mathrm{AF}$ 와 SLF 후방 부위의 단절을 보이며 전방 부위의 추적도를 그릴 수 없었다. SLF와 ILF의 심한 좌측편향 비대칭성의 소실 이 관찰되었고, $\mathrm{UF}$ 의 추적도도 그릴 수 없었다. 본 연구에서의 nerve fiber injury의 조작적 정의에 따르면 등쪽 신경섬유의 중 증도는 3 , 배쪽 신경섬유의 중증도도 2에 해당하였다. .

Table 3은 DTI 영상을 이용하여 관찰한 신경섬유 손상의 부 위와 손상 정도를 나타낸 것으로, 신경섬유의 손상 정도는 신 경섬유의 단절 여부, 추적도를 그릴 수 있는지의 여부 및 좌측 편향 비대칭성의 소실을 기준으로 평가하였다. 정상인의 경우,
신경섬유의 단절이 없고 좌측편향 비대칭성을 보였다. 반면, 환 자들 모두에게서 정도의 차이는 있으나 좌측편향 비대칭성의 소실이 관찰되었다. P4의 경우는 단절 여부에 있어 단절은 있 으나 불완전하게나마 연결을 유지하고 있어 \pm 로 평가하였다. 정상인의 경우, 신경섬유의 단절이 없고 좌측편향 비대칭성을 보였다. 반면, 환자들 모두에게서 정도의 차이는 있으나 좌측편 향 비대칭성의 소실이 관찰되었다. P4의 경우는 단절 여부에 있 어 단절은 있으나 불완전하게나마 연결을 유지하고 있어 \pm 로 평가하였다.

\section{$\mathrm{PK}-\mathrm{WAB}-\mathrm{R}$ 결과}

Table 4에서 보는 바와 같이, $\mathrm{P} 1$ 의 경우 $\mathrm{PK}-\mathrm{WAB}-\mathrm{R}$ 검사 결 과, 실어증지수 14.7로 극심도(very severe)의 중증도(severity) 를 보였고, 브로카실어증으로 진단되었다. $\mathrm{P} 1$ 은 발화를 전혀 하 지 못했으며, 유창성 및 스스로 말하기 원점수는 0점이었다. 청 각적 이해력은 중간 수준으로, 알아듣기 점수 5.95/10점이었는 데, 예/아니오 질문에 대한 수행력은 원점수 51/60점으로 좋은 편이었고, 청각적 낱말 인지는 원점수 43/60점이었으나, 명령 이 행능력에서는 원점수 $25 / 80$ 점으로 길고 복잡한 명령을 전혀 수행하지 못하였다. 따라말하기 점수는 $1 / 10$ 점으로, 1 음절 낱 말에서도 오반응을 보이는 등 매우 낮은 수행력을 보였다. 이름 대기 점수는 $0.4 / 10$ 점으로 사물 이름대기 과제에서 한 단어를 겨우 말하여 원점수 3/60점으로 매우 낮은 수행력을 보였다. 읽기 점수는 9/20점으로, 문장 독해력은 원점수 16/40점이었 고, 쓰기 점수는 8.4/20점으로 쓰기 과제에서는 음소착어가 관 찰되었다.

P2는 실어증지수 96.6으로 경도(mild)의 중증도를 보였으며, 명칭실어증으로 진단되었다. P2의 언어적 특성으로는 "가가", "이거", "그거" 등의 대명사 대치를 보였다. 스스로 말하기

Table 3. Lesion of nerve injury and severity in a normal speaker and patients with acute cerebral hemorrhage

\begin{tabular}{|c|c|c|c|c|}
\hline & Nerve fiber injury & Severity of injury & Disconnection & LLA \\
\hline $\mathrm{N}$ & - & 0 & - & - \\
\hline \multirow[t]{2}{*}{$\mathrm{P} 1$} & AF \& SLF & 3 & + & + \\
\hline & - & 0 & - & - \\
\hline \multirow[t]{2}{*}{ P2 } & AF \& SLF & 1 & - & + \\
\hline & - & 0 & - & - \\
\hline \multirow[t]{2}{*}{ P3 } & $\mathrm{AF} \& \mathrm{SLF}$ & 3 & + & + \\
\hline & ILF \& UF & 3 & + & + \\
\hline \multirow[t]{2}{*}{ P4 } & $\mathrm{AF} \& \mathrm{SLF}$ & 2 & \pm & + \\
\hline & ILF \& UF & 1 & - & + \\
\hline \multirow[t]{2}{*}{ P5 } & $\mathrm{AF} \& \mathrm{SLF}$ & 3 & + & + \\
\hline & ILF \& UF & 2 & + & + \\
\hline
\end{tabular}

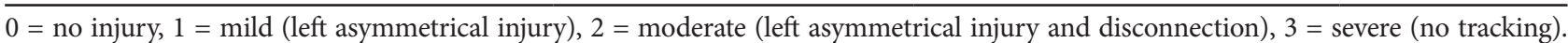
LLA: loss of leftward asymmetry, N: normal, P: patient with aphasia, AF: arcuate fasciculus, SLF: superior longitudinal fasciculus, ILF: inferior longitudinal fasciculus, UF: uncinate fasciculus 
19/20점, 알아듣기 10/10점, 따라말하기 10/10점, 이름대기 9.3/10점을 보이며 높은 수준의 수행력을 보였으나, " 1 분 동안 동물 이름을 생각나는 대로 말하는' 단어유창성 과제에서 $13 / 20$ 점으로 중간 수준의 수행력을 보여 다른 과제들에 비해 서 상대적으로 낮은 수행력을 보였다. 읽기 18.2/20점, 쓰기 19.6/20점으로 비교적 높은 점수를 보였으나, 쓰기에서 '손톱깎 이'를 '슴끔깎이’로 쓰는 등 심한 음소착어가 관찰되었다.

$\mathrm{P} 3$ 는 실어증지수 6 으로 극심도의 중증도를 보였으며, 전반실 어증으로 진단되었다. P3의 경우, 말하지도 알아듣지도 못했으 며, "그렇습니다" 한 가지 표현만 계속 되풀이해서 말하며, 정보 가 없는 자동구어로 웅얼거렸다.

$\mathrm{P} 4$ 는 실어증지수 83으로 경도의 중증도를 보였으며, 연결피 질감각실어증으로 진단되었다. $\mathrm{P} 4$ 의 경우, 유창성 19/20점, 알 아듣기 5.6/10점, 따라말하기 9.6/10점, 이름대기 7.3/10점으로, 특히 알아듣기 과제 중 명령이행 과제에서 원점수 $18 / 80$ 점으로 수행에 어려움을 보였고, 검사자의 말을 따라 말하는 반향어증 이 관찰되었다. 단어유창성에서도 원점수 $5 / 20$ 으로 낮은 수행 력을 보였다. 쓰기 과제에서는 비교적 긴 문장으로 잘 표현하기 는 했으나, '손톱깎이'를 '손톡갉기'로 쓰기도 했고, 'ㄱ O'까지 쓰는 과제에서는 '가기니디로미부시'라고 쓰며 오반응했다. 베껴 쓰기 과제에서도 음소착어와 조사 생략을 보이는 등 원점수 5/10점으로 중등도 수준의 수행력을 보였다.

$\mathrm{P} 5$ 는 실어증지수 44.2로 심도(severe)의 중증도를 보였고, 베 르니케실어증과 연결피질감각실어증으로 진단되었다. 베르니케 실어증과 연결피질감감실어증은 유창성 4점 이상, 알아듣기 7 점 이하, 이름대기 10 점 이하인 점은 같고, 따라말하기에서 8점
이하는 베르니케실어증으로, 7점 이상은 연결피질감각실어증으 로 분류된다. P5의 경우, 따라말하기 7.8점으로 검사 지침에 따 르면 두 유형 모두에 속하였다. P5의 경우, 유창성 7/20점, 알아 듣기 4.8/10점, 따라말하기 7.8/10점, 이름대기 2.5/10점으로 따 라말하기를 제외하고는 모든 과제에서 수행능력이 낮았다. 검 사자가 이름을 묻자 본인의 이름과 다른 이름을 말했고, 다시 말해달라고 하자 “다시 말할 수 없습니다" 하는 말을 계속해서 되풀이했다. 장황하게 말은 하나 무슨 말인지 내용을 알 수 없 는 빈구어를 보이기도 하고, 발화하기 위해 애쓰거나 머뭇거리 는 모습이 검사하는 동안 계속 관찰되었다. 주소에서도 다른 주소를 반복하여 말하며 과유창성을 보였다. 다른 과제에서는 소극적인 반응을 보이다가 따라말하기 과제에서는 적극성을 보 이며 원점수 78/100점으로 다른 과제와 비교해서 상대적으로 높은 수준의 수행력을 보였다. 그러나 쓰기 과제에서는 거의 알 아볼 수 없는 정형화되지 않은 단어를 반복해서 썼다. 글씨로 제시되는 과제를 수행하는 데 극도의 어려움을 보이며 거의 수 행하지 못했다. P5는 유형별 분류에서는 베르니케실어증과 연 결피질감각실어증이 함께 나왔지만, 따라말하기 등의 언어적 특성을 볼 때 베르니케실어증보다는 연결피질감각 실어증의 특 성이 더 많이 관찰되었다. 각 환자별 이름대기 과제에서의 오류 특성을 살펴보면 Table 5 와 같다.

\section{DISCUSSIONS}

본 연구에서는 급성기 뇌출혈 환자의 언어장애 양상에 따른 신경섬유 손상의 특성을 알아보기 위해 급성기 뇌출혈 환자 5

Table 4. Summary of Paradise Korean-Western Aphasia Battery-Revised

\begin{tabular}{ccccccccccc}
\hline Case & $\begin{array}{c}\text { Fluency } \\
(0-20)\end{array}$ & $\begin{array}{c}\text { Auditory } \\
\text { comprehension }(0-10)\end{array}$ & $\begin{array}{c}\text { Repetition } \\
(0-10)\end{array}$ & $\begin{array}{c}\text { Naming } \\
(0-10)\end{array}$ & $\begin{array}{c}\text { AQ } \\
(0-100)\end{array}$ & Severity & Aphasia type & $\begin{array}{c}\text { Reading } \\
(0-20)\end{array}$ & $\begin{array}{c}\text { Writing } \\
(0-20)\end{array}$ & $\begin{array}{c}\text { LQ } \\
(0-100)\end{array}$ \\
\hline N & 20 & 10 & 10 & 10 & 100 & - & - & 20 & 20 & 100 \\
P1 & 0 & 5.95 & 1 & 0.4 & 14.7 & Profound & B & 9 & 8.4 & 30.7 \\
P2 & 19 & 10 & 10 & 9.3 & 96.6 & Mild & A & 18.2 & 19.6 & 96.1 \\
P3 & 3 & 0 & 0 & 0 & 6 & Profound & G & 0 & 0 & 3 \\
P4 & 19 & 5.6 & 9.6 & 7.3 & 83 & Mild & TCS & 5.6 & 15.1 & 67.8 \\
P5 & 7 & 4.8 & 7.8 & 2.5 & 44.2 & Severe & W/TCS & 1.6 & 0.1 & 28.6 \\
\hline
\end{tabular}

AQ: Aphasia Quotient, LQ: Language Quotient, N: normal, P: patient with aphasia, B: Broca, A: anomia, G: global, TCS: transcortical sensory, W: Wernicke

Table 5. Characteristics of naming errors and response

\begin{tabular}{lcl}
\hline \multicolumn{1}{c}{ Case } & Naming scores & \multicolumn{1}{c}{ Naming errors and response } \\
\hline P1 (B) & 0.4 & No response \\
P2 (A) & 9.3 & Substitution with pronoun \\
P3 (G) & 0 & Repetition of automatic speech with no information \\
P4 (TCS) & 7.3 & Echolalia \\
P5 (W/TCS) & 2.5 & Fluent, empty speech \\
\hline
\end{tabular}

P: patient with aphasia, B: Broca, A: anomia, G: global, TCS: transcortical sensory, W: Wernicke 
명과 정상대조군 1명을 대상으로 DTI를 이용하여 신경섬유 손 상에 따른 언어적 특성을 관찰하였다.

먼저 병소 부위와 병소 크기에 따른 언어적 특성을 살펴보면, $\mathrm{CT}$ 및 MRI 영상에서 손상 부위의 크기가 비교적 작은 것(출 혈량 $30 \mathrm{cc}$ 이하)으로 관찰된 환자들의 경우 $\mathrm{PK}-\mathrm{WAB}-\mathrm{R}$ 검사 결과 실어증의 중증도가 중등도 이하로 진단되었다. 병소의 크 기가 클수록 실어증의 정도가 심하게 나타났으며 피질하 구조 물과 피질의 손상이 동시에 있을 때 실어증의 정도가 더 심한 것으로 관찰되었다. 또한, P1과 P5는 피각부 및 전두엽 출혈로 병소 부위가 같음에도 불구하고 브로카실어증과 베르니케실어 증 및 연결피질감각실어증으로 실어증의 유형이 다르게 나타났 는데, 이는 병소 부위와 실어증 유형과는 절대적 상관관계가 없 다는 선행연구의 결과를 뒷받침하고 있다.

신경섬유의 손상 부위와 손상 정도에 따른 언어적 특성을 살 펴보면, 본 연구에 참여한 환자들의 PK-WAB-R 검사 결과, 실 어증으로 진단된 환자들은 모두 DTI 영상에서 신경섬유의 좌 측편향 비대칭성의 소실을 보였으며, 신경섬유의 단절이 관찰되 는 경우 실어증의 정도가 심한 것으로 관찰되었다. 본 연구에서 는 신경섬유의 단절 여부 및 소실 정도에 따라 중증도를 평정 하였는데, P1, P2의 경우, 신경섬유의 손상 부위는 AF와 SLF 로 같고, $\mathrm{P} 4$ 의 경우에도 대부분 $\mathrm{AF}$ 와 $\mathrm{SLF}$ 로 신경섬유 손상 부위가 비슷하지만 중증도에 있어서 차이를 보였는데, $\mathrm{P} 4$ 의 경 우는 신경섬유의 부분적인 단절은 있으나 전체적으로는 연결을 유지하였다. 유창성 점수 및 이름대기 점수에서 비교적 낮은 점 수를 보인 P1, P3, P5 환자에서는 공통적으로 등쪽 신경섬유 즉, $\mathrm{SLF}$ 와 $\mathrm{AF}$ 의 손상이 심하게 나타났다. 특히 브로카실어증 양상을 보인 $\mathrm{P} 1$ 의 경우, 유창성과 따라말하기 및 이름대기에서 매우 낮은 수행력을 보였지만 알아듣기에서는 5.95점으로 중등 도의 수행력을 보였다. 이는 배쪽 경로인 ILF와 UF가 의미론, 통사론적 이해에 관여한다고 한 Lee et al.(2015)의 연구에서처 럼, $\mathrm{P} 1$ 이 등쪽 $\mathrm{AF}$ 와 $\mathrm{SLF}$ 의 심도의 손상으로 인한 심한 말 산 출장애를 보였음에도 배쪽 ILF와 UF가 비교적 잘 유지되어 있 어서 어느 정도 언어 이해력은 유지되고 있음을 의미한다. P1의 DTI에서 등쪽 신경섬유의 전방 부위의 추적도는 그릴 수 없었 으나 등쪽 신경섬유의 후방 부위와 배쪽 신경섬유는 보존되어 있었다. 반면, 등쪽 신경섬유의 후방 부위에서 단절이 관찰되지 만 P4에서는 불완전한 단절을 보이고 있어 P5에 비해 유창성 점수가 상대적으로 높았다. 따라서 언어 유창성에 특히 등쪽 신경섬유의 전방 부위가 중요한 역할을 함을 유추할 수 있었다.

알아듣기 점수에서는 신경섬유의 단절을 보이지 않은 P2가 10 점의 높은 수행력을 보인 것과는 대조적으로 P4, P5는 각각 5.6점과 4.8점으로 높지 않은 수행력을 보였는데, 등쪽 신경섬 유의 후방 부위에서의 단절이 관찰되었다. 또한 브로카실어증
을 보인 P1에서도 알아듣기 점수가 5.95점으로 중등도의 수행 력을 보였다. 이로써 등쪽 신경섬유, 특히 등쪽 신경섬유의 전· 후방 부위에서 전두엽의 운동피질 영역과 측두엽의 감각피질 영 역을 연결하는 $\mathrm{AF}$ 와 배쪽 신경섬유는 언어의 이해와 관련되어 있음을 알 수 있었다. 특히 P5 환자와 같이 배쪽 신경섬유 전방 의 UF 손상이 동반되었을 때는 의미론 및 통사론적 이해가 현 저히 저하됨을 관찰할 수 있었다. 따라말하기 점수가 비교적 높은 P2, P4, P5에서 P2, P4는 배쪽 신경섬유가 보존되어 각각 10점, 9.6점의 높은 점수를 보인 반면, 배쪽 신경섬유의 전방부 즉, $\mathrm{UF}$ 의 심한 손상을 보인 P5에서는 7.8점으로 따라말하기 점 수가 상대적으로 낮게 관찰되었다. 이름대기 점수에서 배쪽 신 경섬유의 손상이 심할수록 낮은 수행력을 보였는데, P5는 2.5 점으로 매우 낮았으며, 특히 단어유창성 및 문장 응답 원점수 는 0점, 문장 완성 원점수는 5점으로 매우 낮은 수행력을 보였 다. Lee et al.(2015)에 의하면 UF는 특히 '단순한' 통사론에 영 향을 미친다고 하였는데, P5의 경우 등쪽 신경섬유의 후방 부 위의 단절과 함께 특히 배쪽 신경섬유의 전방부 즉, UF의 소실 이 관찰되었다.

실어증 유형과 신경섬유 손상의 경우, 본 연구의 조작적 정의 에 의한 신경섬유 손상의 중증도의 합을 기준으로 볼 때, 같은 중증도 3의 P1과 P4의 실어증의 유형이 다르게 나타났으나, 본 연구에서는 신경섬유의 손상 정도와 실어증의 유형 간의 관계 는 알 수 없었다.

$\mathrm{P} 1$ 과 P5에서는 피각부 및 전두엽 출혈로 병소 부위가 같음 에도 불구하고 실어증 유형에서 P1은 브로카실어증으로, P5는 베르니케 및 연결피질감각실어증으로 서로 다르게 나타났는데, 이는 신경섬유의 손상 부위가 서로 다른 데 기인한 결과이며 신경섬유 손상 부위와 정도가 언어적 양상에 미치는 영향을 입 증한 것이다. $\mathrm{P} 1$ 은 등쪽 신경섬유의 전·후방 부위의 소실과 중 간 부위의 단절을 보였고, $\mathrm{P} 5$ 는 등쪽 신경섬유의 후방 부위의 단절과 배쪽 신경섬유의 전방 부위의 소실로 신경섬유 손상 부 위가 달랐다. 이렇게 병소 부위가 같음에도 불구하고 신경섬유 손상 부위가 다르게 나타나는 것은 뇌출혈 환자에 있어 원발성 출혈이 유발하는 일차적인 피질의 손상보다는 주로 뇌심부에 서 출혈을 일으켜 피질로 확장되면서 발생하는 이차적 손상으 로 인해 균일하지 않은 피질의 손상이 발생하기 때문인 것으로 추정된다. 또한 피각부에 국한된 뇌출혈이 발생한 P2에서는 백 질의 직접적인 손상이 없었음에도 좌측편향 비대칭성의 소실 이 관찰되었고 명칭실어증의 양상을 보였다. 이는 혈종 자체에 의해 주변의 뇌 조직을 압박하는 종괴 효과(mass effect) 또는 출혈로 인한 갑작스런 뇌부종이나 뇌압 상승이 원인이 되어 병 소 부위 외에 다른 부위의 신경섬유의 손상이 동반될 수 있음 을 시사한다. 
따라서, 본 연구를 통하여 신경섬유의 손상 부위와 손상 정 도가 언어장애의 양상과 중증도에 중요한 영향으로 작용함을 분명하게 확인할 수 있었다. 또한 병소 부위와 다른 언어적 양 상을 보이는 환자들에 대해, 뇌 영상을 직접 보고 DTI를 이용 하여 신경섬유들을 통합적으로 관찰하고 손상 부위와 손상 정 도를 시각화하여 가시적으로 비교·분석함으로써 그 원인을 유 추해낼 수 있었다. 임상 현장에서 DTI를 이용하여 환자들의 언 어장애의 특성을 보다 정확하게 진단하고 예측해낼 수 있게 된 다면 환자들에게 보다 적절하고 빠른 치료 계획의 수립과 조기 중재를 제공할 수 있음은 물론이고, 현실적으로 그에 따른 시간 적·경제적 절감도 예상할 수 있을 것이다. 더 나아가 환자들에 게 정확한 진단을 통한 치료를 제공함으로써 검사 자체와 치료 사에 대한 환자의 신뢰도 또한 높일 수 있을 것으로 기대한다.

본 연구의 제한점과 후속연구를 위한 제언은 다음과 같다. 본 연구에서는 병소 부위뿐만 아니라 신경섬유의 손상 부위와 손상 정도에 따라 언어장애의 양상이 다르게 나타날 수도 있 음을 확인할 수 있었다. 그러나 사례의 부족으로 언어장애 양 상과 신경섬유 손상 부위 및 손상 정도와의 상관관계를 일반화 시키는 데는 무리가 있었다. 향후 보다 더 많은 환자군들에 대 한 연구를 통하여 이러한 문제점들을 보완할 필요가 있을 것이 다. 또한 급성기와 더불어 만성기 환자들의 실어증 회복에 따른 언어적 양상의 변화와 신경섬유 손상의 정도와 손상 부위의 변 화를 관찰해본다면 이들의 상관관계를 더욱 명확히 확인해볼 수 있을 것이다.

중심 단어 : 실어증·한국판 웨스턴 실어증 검사-개정판·확산 텐서 이미지·뇌출혈·백질 신경 경로.

\section{Ethical Statement}

This study was approved by the Institutional Review Board of Daegu Catholic University (IRB \# CUIRB-2015-17255).

\section{Acknowledgments}

The authors would like to thank all patients and Dr. Sang Wook Lee \& Ji Kang Park in S pohang hospital.

\section{Declaration of Conflicting Interests}

There are no conflict interests.

\section{Funding}

N/A

\section{REFERENCES}

Banich, M. T. \& Compton, R. J. (2014). Cognitive Neuroscience. Seoul: Pakhaksa.

Bohra, V., Khwaja, G. A., Jain, S., Duggal, A., Ghuge, V. V., \& Srivastava, A. (2015). Clinicoanatomical correlation in stroke related aphasia. Annals of Indian Academy of Neurology, 18(4), 424-429.

Breier, J. I., Hasan, K. M., Zang, W., Men, D., \& Papanicolau, A. C. (2008). Language dysfunction after stroke and damage to white matter tracts evaluated using diffusion tensor imaging. American Journal of Neuroradiology, 29(3), 483-487.

Brunner, R. J., Kornhuber, H. H., Seemüller, E., Suger, G., \& Wallesch, C. W. (1982). Basal ganglia participation in language pathology. Brain and Language, 16(2), 281-299.

Galantucci, S., Tartaglia, M. C., Wilson, S. M., Henry, M. L., Filippi, M., Agosta, F., et al. (2011). White matter damage in primary progressive aphasias: A diffusion tensor tractography study. Brain, 134(Pt 10), 30113029.

Hosomi, A., Nagakane, Y., Yamada, K., Kuriyama, N., Mizuno, T., Nishimura, T., et al. (2009). Assessment of arcuate fasciculus with diffusion-tensor tractography may predict the prognosis of aphasia in patients with left middle cerebral artery infarcts. Neuroradiology, 51(9), 549-555.

Jeong, H. W., Yang, H. S., Yang, H. E., Shim, H. A., \& Kang, H. K. (2009). Global aphasia without hemiparesis: A case report. Brain and Neurorehabilitation, 2(2), 155-158.

Kim, H. H. (2012). Neurologic Speech-Language Disorders. Seoul: Sigmapress.

Kim, H. H. \& Na. D. R. (2012). Paradise Korean-Western Aphasia BatteryRevised. Seoul: paradise Welfare Foundation.

Kim, S. H. \& Jang, S. H. (2013). Prediction of aphasia outcome using diffusion tensor tractography for arcuate fasciculus in stroke. American Journal of Neuroradiology, 34(4), 785-790.

Kim, S. H., Lee, D. G., You, H., Son, S. M., Cho, Y. W., Chang, M. C., et al. (2011). The clinical application of the arcuate fasciculus for stroke patients with aphasia: A diffusion tensor tractography study. NeuroRehabilitation, 29(3), 305-310.

Lee, S. J., Lee, S. J., Song, J. Y., Kim, G. Y., \& Kim, H. H. (2015). White matter connectivity as a neurophysiological mechanism for auditory comprehension in the neurologically normal and impaired. Communication Sciences and Disorders, 20(1), 121-132.

Park, K. W. (2003). Analysis of aphasia patients resulting from acute ischemic strock using quantitative methods of aphasia test. Journal of the Korean Geriatrics Society, 7(1), 55-64.

Rilling, J. K., Glasser, M. F., Preuss, T. M., Ma, X., Zhao, T., Hu, X., et al. (2008). The evolution of the arcuate fasciculus revealed with comparative DTI. Nature Neuroscience, 11(4), 426-428.

Seikel, J. A., King, D. W., \& Drumright, D. G. (2015). Anatomy \& Physiology for Speech, Language, and Hearing. Seoul: Pakhaksa. 